\title{
Long-term use of topical tacrolimus ointment: a safe and effective option for the treatment of vernal keratoconjunctivitis
}

\author{
Uso prolongado de tacrolimus tópico: opção eficaz e segura no \\ tratamento da ceratoconjuntivite vernal
}

\author{
Guilherme Gubert Müller', Newton Kara José', Rosane Silvestre de Castro', Erick Carneiro de Holanda' \\ 1. Department of Ophthalmology and Otolaryngology, Faculdade de Ciências Médicas, Universidade Estadual de Campinas, Campinas, SP, Brazil.
}

\begin{abstract}
Purpose: To assess the compliance, efficacy, and safety of the long-term use of topical tacrolimus for the clinical management of vernal keratoconjunctivitis. Methods: The medical records of patients with vernal keratoconjunctivitis undergoing long-term treatment with $0.03 \%$ topical tacrolimus were retrospectively reviewed. The duration of tacrolimus use and the causes for drug discontinuation were used to assess treatment compliance. To assess drug efficacy, the need for and the number of times that topical corticosteroids were used to control symptoms were registered. Side effects related to tacrolimus use were monitored to determine drug safety. Results: The study cohort consisted of 21 patients who met the eligibility criteria. The mean duration of tacrolimus use was $41.3 \pm 18.5$ months. Fourteen patients $(66.7 \%)$ continuously used tacrolimus, and three (14.3\%) discontinued treatment following complete remission. Four patients (19\%) did not use tacrolimus as prescribed or interrupted tacrolimus use on their own: two (9.5\%) because of discomfort upon application and two (9.5\%) because of the lack of improvement. Ten patients (47.6\%) maintained disease control without the use of corticosteroids, whereas 11 (52.4\%) required an average of $2.70 \pm 1.35$ corticosteroid cycles to control symptoms. The only reported side effect was discomfort upon application. Conclusions: Despite the small sample size and study design limitations, these results support the long-term use of topical tacrolimus as an effective and safe option for the treatment of vernal keratoconjunctivitis, with good compliance of patients to the treatment.
\end{abstract}

Submitted for publication: April 19,2018

Accepted for publication: July 24, 2018

Funding: No specific financial support was available for this study.

Disclosure of potential conflicts of interest: None of the authors have any potential conflicts of interest to disclose.

Corresponding author: Guilherme Gubert Müller

Av. Desembargador Hugo Simas, 333 - Curitiba, PR - 82520-250 - Brasil E-mail: gubertmuller@gmail.com

Approved by the following research ethics committee: Universidade Estadual de Campinas (\# 84192616.7.00005401).
Keywords: Cornea, Vernal keratoconjunctivitis, Tacrolimus, Allergic conjunctivitis, Antiallergic drugs

RESUMO | Objetivo: Avaliar a aderência, a eficácia e segurança do uso prolongado de tacrolimus tópico no controle clínico da ceratoconjuntivite vernal. Métodos: Um estudo retrospectivo foi desenvolvido através da análise de prontuários de pacientes com ceratoconjuntivite vernal em tratamento prolongado com tacrolimus tópico $0,03 \%$. A duração do tempo de uso do tacrolimus e as causas de descontinuação da medicação foram usadas para avaliar a adesão ao tratamento. Para avaliar a eficácia da droga, a necessidade e o número de vezes em que corticoides tópicos foram utilizados para controlar os sintomas foram registrados. Os efeitos colaterais relacionados ao uso do tacrolimus foram monitorados para determinar a segurança da droga. Resultados: Vinte e um pacientes preencheram os critérios de eleição e foram incluídos no estudo. A duração média do uso de tacrolimus foi de 41,3 $\pm 18,5$ meses. Quatorze pacientes $(66,7 \%)$ usaram continuamente o tacrolimus e $3(14,3 \%)$ descontinuaram o tratamento após a remissão completa. Quatro pacientes (19\%) não usaram o tacrolimus conforme prescrito ou interromperam o uso da droga isoladamente: $2(9,5 \%)$ por desconforto na aplicação e $2(9,5 \%)$ pela falta de melhora. Dez pacientes $(47,6 \%)$ mantiveram a doença sob controle sem o uso de corticoides, enquanto $11(52,4 \%)$ necessitaram em média $2,70 \pm 1,35$ ciclos corticoides para controle dos sintomas. $\mathrm{O}$ único efeito adverso relatado foi desconforto na aplicação. Conclusões: Apesar do pequeno tamanho da amostra e das limitações do desenho do estudo, esses resultados suportam o uso prolongado do tacrolimus tópico como opção eficaz e segura para o tratamento da ceratoconjuntivite vernal, com boa adesão dos pacientes ao tratamento.

Descritores: Ceratoconjuntivite vernal, ceratoconjuntivite primaveril, tacrolimus, conjuntivite alérgica, antialérgicos

\section{INTRODUCTION}

Vernal keratoconjunctivitis (VKC) is an allergic disease that affects children and young adults and is one 
of the most severe forms of atopic ocular disease. Classically, the incidence of VKC peaks in the summer and spring. However, $60 \%$ of cases can become chronic with persistent symptoms ${ }^{(1)}$. The course of VKC is self-limited with initial symptoms appearing at the age of approximately 7 years and peaks between the ages of 11 and 13 years. VKC is more prevalent in boys until the age of 14 years, but this tendency decreases at the age of 20 years, when the disease prevalence is equal between the sexes.

Clinical signs of VKC include conjunctival hyperemia and a significant papillary reaction of the tarsal, particularly of the upper tarsal. VKC may cause different lesions, from punctate epithelial keratopathy to ulcerations, with corneal neovascularization and conjunctival fibrosis at later stages ${ }^{(2-4)}$. VKC is mainly characterized by intense itching, but patients also frequently complain of lacrimation, foreign body sensation and photopho$\mathrm{bia}^{(3,5)}$. There are three different clinical forms of VKC: the palpebral form, which is characterized by giant papillae in the upper tarsal; the limbal form, with gelatinous nodules composed of eosinophilic infiltrates and degenerated epithelial cells (Horner-Tantras dots); and a mixed form ${ }^{(1)}$.

Among the most frequent complications of VKC, keratoconus stands out because of its high incidence and greater severity of ectasia; therefore, good management of symptoms is imperative during the active phase of the disease. A large number of studies have correlated the act of rubbing the eyes with the advancement of keratoconus ${ }^{(6-11)}$. Although the pathophysiology of this mechanism remains unknown, some studies have suggested that chronic mechanical trauma to the corneal epithelium can result in the prolonged release of small quantities of enzymes that lead to the disruption of collagen fibers ${ }^{(10)}$.

The treatment of VKC involves, in addition to environmental control measures, the use of anti-histamines (Als) and topical mast cell stabilizers (MCSs), which are usually sufficient to control symptoms in mild cases ${ }^{(12,13)}$. However, a high number of patients are refractory to allergy therapy and require treatment with topical steroids. Side effects related to long-term steroid use, such as increased intraocular pressure, cataract development, and increased susceptibility to infections, limit its use to short cycles of topical steroids $s^{(3,14)}$.

The development of new immunomodulatory drugs with mechanisms of action similar to that of steroids, but without its side effects, appears as a treatment option for these patients. Tacrolimus (TCL), a macrolide immuno- suppressant derived from Streptomyces tsukubaensis, is an alternative to steroid therapy for allergic diseases of the ocular surface. TCL acts on CD4+ T lymphocytes preventing IL-2 production by inhibiting calcineurin, thereby blocking the inflammatory cascade and the recruitment of eosinophils, an important step in the pathogenesis of the disease. In addition, TCL also acts on mast cells as a membrane stabilizer by inhibiting the release of histamines and the production of prostaglandins ${ }^{(15-17)}$.

Several studies have demonstrated the effective control of symptoms and signs in VKC patients who use topical $\mathrm{TCL}$, avoiding the long-term use of steroids and the subsequent side effects ${ }^{(18-21)}$. However, few studies have monitored long-term TCL therapy in VKC patients.

The objective of this study was to assess the compliance, efficacy, and safety of long-term therapy with topical TCL for the clinical management of VKC.

\section{METHODS}

In this non-randomized study, the medical records of VKC patients being followed up at the External Diseases Outpatient Clinic of the Clinics Hospital of the State University of Campinas from February 2011 to September 2017 were retrospectively reviewed. The diagnosis of VKC was based on a clinical history of recurrent/persistent conjunctivitis associated with intense ocular itching and a marked papillary reaction with giant papillae in the upper tarsus and/or Horner-Tantras dots in both eyes. The therapeutic scheme followed a standard flowchart, as depicted in figure 1.

The patients selected to participate in this study had already used or were currently using topical TCL for the management of VKC. A dermatologic formulation of $0.03 \%$ TCL ointment (Protopic ${ }^{\circledR}$; Astellas Pharma Tech Co., Ltd., Toyama, Japan) was prescribed to patients for application on the conjunctival fornix every $12 \mathrm{~h}$. Proper use of this off-label drug was explained to the patient and/ or person responsible for the treatment, who also signed an informed consent form after agreement to participate in this study.

VKC was considered to be under control if the patient reported significant improvement of the following symptoms without interference with daily activities: reduction of itching until there was no urge to rub the eyes and reductions in the incidences of lacrimation, foreign body sensation, and photophobia.

The duration of TCL use was registered, and compliance to treatment was defined as adherence to the 
medical prescription. Those patients who discontinued the medication or did not use TCL as prescribed were considered non-compliant. The reasons for non-compliance were registered.

For cases in which symptoms were not under control (active disease), short cycles of steroids with tapering doses were prescribed (Figure 1). The need to add a topical steroid to the treatment regimen and the number of steroid cycles prescribed were used as inversely proportional parameters to assess treatment efficacy. The medical decision to use high- or low-penetration steroids was made on a case-by-case basis.

To determine drug safety, the incidence of side effects related to TCL use was assessed. Al and MCS drugs were used as necessary; however, the patients were advised against more than two applications per day.

\section{RESULTS}

Of 42 patients being followed up for VKC in the outpatient clinic, 24 had used or were using topical TCL until the time of data collection. Three patients discontinued TCL use because of a lack of economic resources and

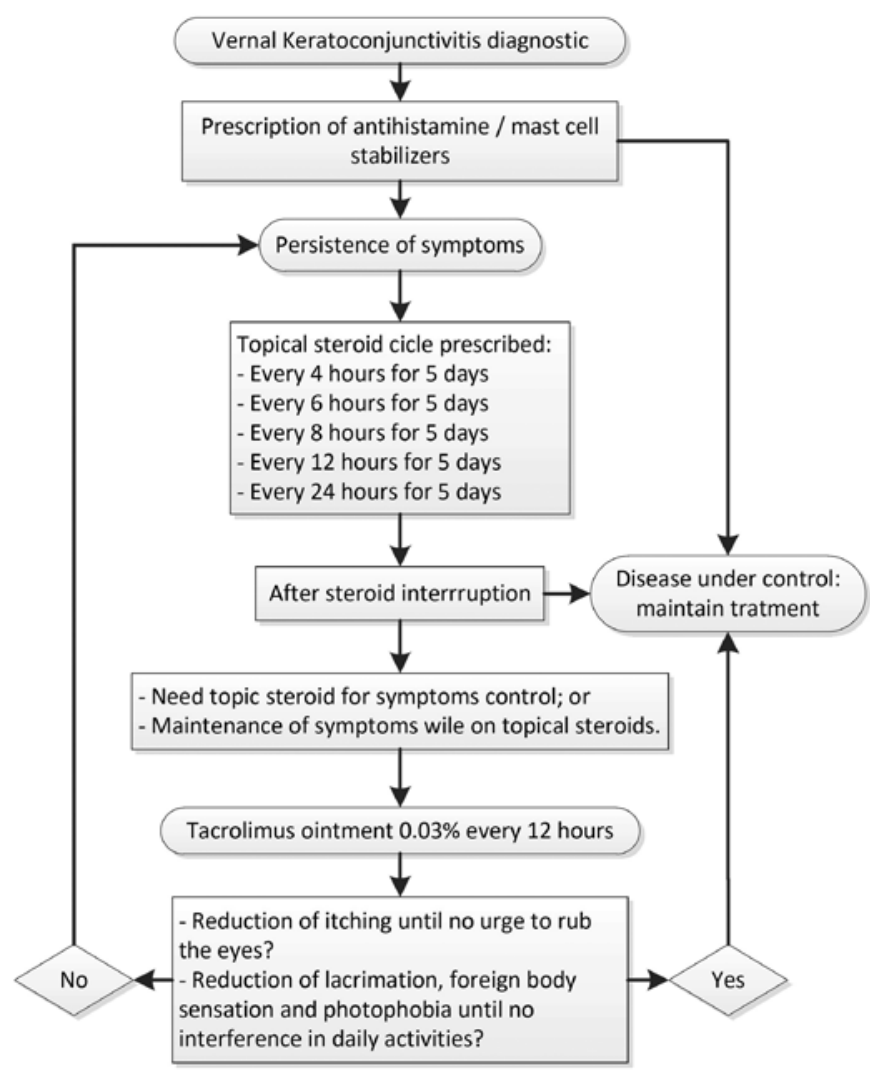

Figure 1. VKC treatment protocol. were excluded from the study. Of the 21 patients assessed, 8 were female and 13 were male, with a mean age of 12 (range, 7-23) years. Patients who did not use TCL $(n=18)$ managed VKC with Al and MCS drugs.

The mean duration of TCL use among the study participants was $41.3 \pm 18.5$ (range, 6-45) months. Of these patients, $14(66.7 \%)$ with VKC used TCL continuously and $3(14.3 \%)$ discontinued TCL use following complete remission (patients used TCL for 14, 30 and 40 months). The mean duration of TCL use for these 17 (81\%) patients was $45 \pm 16.9$ months. The remaining four (19\%) patients did not use TCL according to the medical prescription or discontinued its use on their own: two (9.5\%) because of discomfort upon TCL application and two $(9.5 \%)$ because of no perceived improvement. The mean duration of TCL use for these four patients was $25 \pm 17.6$ months.

Ten (47.6\%) patients achieved disease control without the use of steroids. Of these, seven patients used TCL continuously and three discontinued use following the complete remission of symptoms. Steroids were necessary to manage disease in $11(52.4 \%)$ patients, with a mean of $2.70 \pm 1.35$ (range, 1-5) cycles/patient as described in figure 1. Of these, seven patients used TCL continuously (mean, 2.5 cycles) and four used TCL irregularly or discontinued TCL use on their own (mean, 3.5 cycles).

Two patients discontinued TCL use because of discomfort upon application (i.e., transient burning sensation, photophobia, and tearing). No other side effects were reported by the patients during the study period (Figure 2).

\section{DISCUSSION}

In this study, compliance to the topical TCL regimen was high, as 17 (80.9\%) of 21 patients used TCL as prescribed. The duration of TCL use was higher in this group of patients as compared with those who discontinued treatment without a medical decision. The efficacy of TCL as an alternative to steroid treatment for VKC was also demonstrated by fewer steroid cycles among patients who regularly used TCL. The hypothesis that TCL has a beneficial effect on VKC management is supported by the fact that all patients who did not add steroids to their treatment regimen used TCL continuously during the study period.

The optimal concentration of TCL remains under discussion, as doses described in the literature range from $0.01 \%$ to $1 \%$. Because no ophthalmologic formulation 


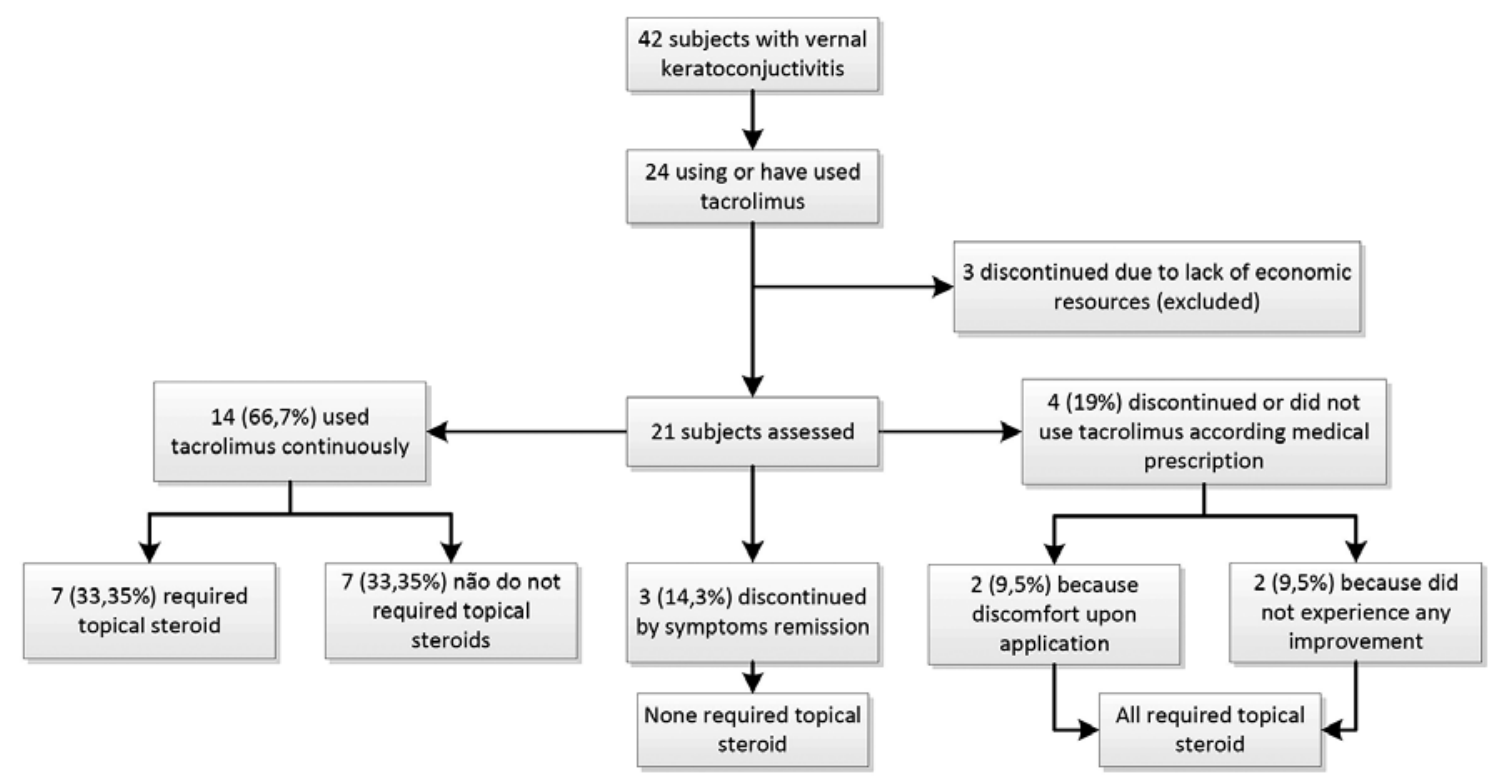

Figure 2. Participant flowchart.

is commercially available, a dermatological ointment was chosen for use on the basis of descriptions in the literature of good efficacy and tolerability without significant side effects $^{(18,20,22,23)}$. We decided to use a lower concentration $(0.03 \%)$ because, in addition to the fact that such a dose has resulted in a good therapeutic response in other studies, the formulation of TCL for VKC is not commercially available and the side effects are unknown.

In a study involving atopic keratoconjunctivitis patients who used $0.1 \%$ topical TCL continuously for 49 months, Al-Amri et al. observed that all patients achieved disease management without the use of CTCs or other drugs ${ }^{(24)}$. Labcharoenwongs et al. observed a significant improvement of symptoms with the use of $0.1 \%$ topical TCL without the need to add steroids or other drugs to control the disease ${ }^{(25)}$. In a case report, Zribi et al. added $0.03 \%$ TCL to the treatment regimens of four patients with atopic keratoconjunctivitis and discontinued steroid use ${ }^{(26)}$.

The absence of serious side effects during this study highlights the safety of prolonged use of TCL. Discomfort upon application, with complaints of transient burning, photophobia, and lacrimation, was the most frequent side effect and was also the reason for treatment discontinuation in two patients. Although there are descriptions in the literature, no case of herpetic keratitis or other ocular surface infectious disease associated with topical TCL was reported ${ }^{(26,27)}$.

Even though three patients achieved complete remission of symptoms after 14, 30 and 40 months of TCL treatment and were thus able to discontinue TCL therapy, two others discontinued TCL treatment because of the absence of improvement even following long-term TCL treatment (10 and 36 months). Even if studies reveal equivalent effects of dexamethasone and topical TCL in experimental models of allergy, the need to add topical steroids in these cases points to a limitation of TCL therapy and the reduced efficacy of TCL for the management of the inflammatory process, as compared with steroids ${ }^{(28)}$.

The option to not restrict the use of Als and MCSs was based on a previous study of the same group of patients, which demonstrated neither benefit nor harm associated with the co-administration of TCL and olopatadine ${ }^{(29)}$.

The high cost of medication is a limiting factor for some patients. Three patients used TCL irregularly and discontinued its use because of a lack of economic resources, even though they experienced symptom improvement. Although there has been a reduction in recent years, the monthly price of TCL remains about six-fold higher than topical dexamethasone 8.50 vs. 1.88 USD, respectively ${ }^{(30)}$.

Despite the limitations regarding the sample size and study design, the results of this study support the use of topical TCL as an effective and safe option for the treatment of VKC, with good patient compliance. Further studies with longer follow-up periods and larger samples are necessary to confirm this hypothesis. 


\section{REFERENCES}

1. Abelson MB, Schaefer K. Conjunctivitis of allergic origin: immunologic mechanisms and current approaches to therapy. Surv Ophthalmol. 1993;38 Suppl:115-32.

2. Barney NP. Vernal and Atopic Keratoconjunctivitis. In: Krachmer $\mathrm{JH}$, Mannis MJ, Holland EJ, editors. Cornea: fundamentals, diagnosis and management. 3nd ed. Philadelphia: Elsevier/Mosby; 2011. p. 1-2.

3. Bonini S, Bonini S, Lambiase A, Marchi S, Pasqualetti P, Zuccaro O, et al. Vernal keratoconjunctivitis revisited: a case series of 195 patients with long-term followup. Ophthalmology. 2000;107(6): 1157-63.

4. Kumar S. Vernal keratoconjunctivitis: a major review. Acta Ophthalmol. 2009;87(2):133-47.

5. Bonini S, Sacchetti M, Mantelli F, Lambiase A. Clinical grading of vernal keratoconjunctivitis. Curr Opin Allergy Clin Immunol. 2007;7(5):436-41.

6. Gautam V, Chaudhary M, Sharma AK, Shrestha GS, Rai PG. Topographic corneal changes in children with vernal keratoconjunctivitis: A report from Kathmandu, Nepal. Cont Lens Anterior Eye. 2015;38(6):461-5.

7. Merdler I, Hassidim A, Sorkin N, Shapira S, Gronovich Y, Korach Z. Keratoconus and allergic diseases among Israeli adolescents between 2005 and 2013. Cornea. 2015;34(5):525-9.

8. Carlson AN. Expanding our understanding of eye rubbing and keratoconus. Cornea. 2010;29(2):245.

9. Jafri B, Lichter H, Stulting RD. Asymmetric keratoconus attributed to eye rubbing. Cornea. 2004;23(6):560-4.

10. McMonnies CW. Mechanisms of rubbing-related corneal trauma in keratoconus. Cornea. 2009;28(6):607-15.

11. Panahi-Bazaz MR, Sharifipour F, Moghaddasi A. Bilateral Keratoconus and Corneal Hydrops Associated with Eye Rubbing in a 7-year-old Girl. J Ophthalmic Vis Res. 2014;9(1):101-5.

12. Leonardi A. Vernal keratoconjunctivitis: pathogenesis and treatment. Prog Retin Eye Res. 2002;21(3):319-39.

13. Kari O, Saari KM. Updates in the treatment of ocular allergies. J Asthma Allergy. 2010;3:149-58.

14. Tabbara KF. Ocular complications of vernal keratoconjunctivitis. Can J Ophthalmol. 1999;34(2):88-92.

15. Zhai J, Gu J, Yuan J, Chen J. Tacrolimus in the treatment of ocular diseases. BioDrugs. 2011;25(2):89-103.

16. Kino T, Hatanaka H, Hashimoto M, Nishiyama M, Goto T, Okuhara $M$, et al. FK-506, a novel immunosuppressant isolated from a Streptomyces. l. Fermentation, isolation, and physico-chemical and biological characteristics. J Antibiot (Tokyo). 1987;40(9):1249-55.

17. de Paulis A, Stellato C, Cirillo R, Ciccarelli A, Oriente A, Marone
G. Anti-inflammatory effect of FK-506 on human skin mast cells. J Invest Dermatol. 1992;99(6):723-8.

18. Tam PM, Young AL, Cheng LL, Lam PT. Topical tacrolimus $0.03 \%$ monotherapy for vernal keratoconjunctivitis-case series. Br J Ophthalmol. 2010;94(10):1405-6.

19. Kheirkhah A, Zavareh MK, Farzbod F, Mahbod M, Behrouz MJ. Topical $0.005 \%$ tacrolimus eye drop for refractory vernal keratoconjunctivitis. Eye (Lond). 2011;25(7):872-80.

20. Attas-Fox L, Barkana Y, Iskhakov V, Rayvich S, Gerber Y, Morad Y, et al. Topical tacrolimus $0.03 \%$ ointment for intractable allergic conjunctivitis: an open-label pilot study. Curr Eye Res. 2008; 33(7):545-9.

21. Vichyanond P, Tantimongkolsuk C, Dumrongkigchaiporn P, Jirapongsananuruk $\mathrm{O}$, Visitsunthorn $\mathrm{N}$, Kosrirukvongs $\mathrm{P}$. Vernal keratoconjunctivitis: result of a novel therapy with $0.1 \%$ topical ophthalmic FK-506 ointment. J Allergy Clin Immunol. 2004; 113(2):355-8.

22. Kymionis GD, Goldman D, Ide T, Yoo SH. Tacrolimus ointment $0.03 \%$ in the eye for treatment of giant papillary conjunctivitis. Cornea. 2008;27(2):228-9.

23. Kymionis GD, Kankariya VP, Kontadakis GA. Tacrolimus ointment $0.03 \%$ for treatment of refractory childhood phlyctenular keratoconjunctivitis. Cornea. 2012;31(8):950-2.

24. Al-Amri AM. Long-term follow-up of tacrolimus ointment for treatment of atopic keratoconjunctivitis. Am J Ophthalmol. 2014; 157(2):280-6.

25. Labcharoenwongs $P$, Jirapongsananuruk O, Visitsunthorn N, Kosrirukvongs $\mathrm{P}$, Saengin $\mathrm{P}$, Vichyanond $\mathrm{P}$. A double-masked comparison of $0.1 \%$ tacrolimus ointment and $2 \%$ cyclosporine eye drops in the treatment of vernal keratoconjunctivitis in children. Asian Pac J Allergy Immunol. 2012;30(3):177-84.

26. Zribi H, Descamps V, Hoang-Xuan T, Crickx B, Doan S. Dramatic improvement of atopic keratoconjunctivitis after topical treatment with tacrolimus ointment restricted to the eyelids. J Eur Acad Dermatol Venereol. 2009;23(4):489-90.

27. Ohashi Y, Ebihara N, Fujishima H, Fukushima A, Kumagai N, Nakagawa Y, et al. A randomized, placebo-controlled clinical trial of tacrolimus ophthalmic suspension $0.1 \%$ in severe allergic conjunctivitis. J Ocul Pharmacol Ther. 2010;26(2):165-74.

28. Shoji J, Sakimoto T, Muromoto K, Inada N, Sawa M, Ra C. Comparison of topical dexamethasone and topical FK506 treatment for the experimental allergic conjunctivitis model in BALB/c mice. Jpn J Ophthalmol. 2005;49(3):205-10.

29. Müller GG, José NK, de Castro RS. Topical tacrolimus $0.03 \%$ as sole therapy in vernal keratoconjunctivitis: a randomized double-masked study. Eye Contact Lens. 2014;40(2):79-83.

30. Consulta Remédios: Compare preços de medicamentos [Internet]. Curitiba; 2018. [citado 2018 Ago 1]. Dsponível em: http://consultaremedios.com.br 